\title{
Calcium oxalate content from two Amazonian amilaceous roots and the functional properties of their isolated starches
}

\author{
Amanda da Silva RAMOS ${ }^{1}$, Rachel de Melo VERÇOSA ${ }^{1}$, Sheylla Maria Luz TEIXEIRA ${ }^{2}$, \\ Bárbara Elisabeth TEIXEIRA-COSTA ${ }^{1,3 *}$ (D)
}

\begin{abstract}
The calcium oxalate content from two Amazonian amilaceous roots, Xanthosoma sagittifolium and Pachyrhizus tuberosus, before and after cooking were studied in the present work. Calcium oxalate raphides were observed by light microscopy in longitudinal sections from fresh tubers. The functional properties and physicochemical characteristics of isolated starches from both species were also investigated. Starches granules were observed with scanning electronic microscopy and presented a typical oval-circular shape, smooth surfaces and size ranging from $3.6 \mu \mathrm{m}$ to $14 \mu \mathrm{m}$. Lower gel clarity, slightly high water-binding capacity, A-type starch structure and low values of crystallinity degree were determined in the isolated starches. High intensity bands related to vibrations of glucosidic bonds of polysaccharides were observed by infrared spectroscopy in both starches. Thermal degradation behavior data of the isolated starches reveled high initial decomposition temperatures. Thus, the studied cooked tubers presented low levels of calcium oxalates and are safe to be consumed as a boiled vegetable. Their isolated starches possess good functional characteristics to be applied as an ingredient to products in food industry.
\end{abstract}

Keywords: Xanthosoma sagittifolium; Pachyrhizus tuberosus; edible tubers; starch; calcium oxalate.

Practical Application: Application as a cassava starch substitute and development of vegan food products.

\section{Introduction}

Cocoyam, taro, aerial yams and other tuberous roots are nutritive and relevant crops to several tropical countries in South America, Africa, Asia and Oceania (Londoño-Restrepo et al., 2018; Otegbayo et al., 2014). Tubers are subsistence foods and rich sources of energy to human diet, especially for those who have poor access to others food resources. These amilaceous food are vital crops to indigenous communities and are related to their culture and traditions (Boakye et al., 2018). Tuberous roots can be consumed as cooked vegetables, as a flour or as an isolated starch (Uchechukwu-Agua et al., 2015). Starches are a diverse and useful ingredient for industrial food applications, such as thickeners, fillers, gelling and water holding agents (Odeku, 2013; Zhu, 2016). Researches about starch sources from untraditional tuberous roots has raised due to their functional properties and to the intense demand of carbohydrates in food and pharmaceutical industries (Londoño-Restrepo et al., 2014; Odeku, 2013). Starch properties, such as, shape and granules size, as well as its crystallinity pattern, water binding capacity and thermodegradation behavior, are important factors to be considered when applied into products (Jayakody et al., 2007).

Tayobe or Cocoyam belongs to the Araceae family, which the Xanthosoma is a significant genus used as food, even though commercially underexplored (Falade \& Okafor, 2013). This genus comprises more than 50 species, with special emphasis to X. sagittifolium (L.) Schott, which is one of the most economically important (Boakye et al., 2018). The nutritional profile of this tuber is related to carbohydrates $(33-36 \mathrm{~g} / 100 \mathrm{~g})$, proteins $(3.9-5.5 \mathrm{~g} / 100 \mathrm{~g})$ and fibers (1.1-1.7 g/100g) (Sefa-Dedeh \& Agyir-Sackey, 2004). However, due to oxalates content in all parts of $X$. sagittifolium, which reflects in acridity taste and irritative reactions, their fresh consumption is limited (Boakye et al., 2018; Sefa-Dedeh \& Agyir-Sackey, 2004). Their tubers are consumed as a boiled vegetable, as a flour, and as starch (Graf et al., 2018). Starches from $X$. sagittifolium presented a Lego-like shape with diameters ranging from 8 to $35 \mu \mathrm{m}$, an A-type diffraction pattern and a crystallinity of 45\% (Graf et al., 2018; Zhu, 2016).

Another edible tuberous root native from South and Central America is the genus Pachyrhizus, commonly named as yam bean or jacatupé (Forsyth et al., 2002; Ramos-de-la-Peña et al., 2013). This genus belongs to the botanical family of Fabaceae (Díaz et al., 2016). The major nutrients present in the tuber of Pachyrhizus ssp. are carbohydrates (47.8-65.0\%) and proteins (7.4-11.5\%) as reported by some authors (Ascheri et al., 2014; Díaz et al., 2016; Ramos-de-la-Peña et al., 2013). High carbohydrates and fibers, as well as vitamins and minerals contributed to classify this tuber as a health energy food (Ramos-de-la-Peña et al., 2013). A high starch content, approximately $83 \%$ in dry matter, plus a significant production yield of $5.0 \mathrm{~kg} / \mathrm{m}^{2}$ (Ramos-de-la-Peña et al., 2013) contributes to starch agroindustry, which may turn P. tuberosus an attractive resource for the sector. Pachyrhizus ssp starch revealed a circular and polygonal microstructural shape of 10-25 $\mu \mathrm{m}$, and low pasting temperature of $56^{\circ} \mathrm{C}$ (Ramos-de-la-Peña et al., 
2013). Starches structural organization reflects in crystallinity patterns and consequently influence on gelatinization process (Deepika et al., 2013).

The aim of this study is to determine the proximate composition of two roots from the Amazon region, Xanthosoma sagittifolium and Pachyrhizus tuberosus, to evaluate the cooking effect in their calcium oxalate content, and physicochemically characterize their isolate starches as a potential resource of carbohydrates to food industry.

\section{Materials and methods}

\subsection{Materials}

Fresh roots from Xanthosoma sagittifolium (XA) and Pachyrhizus tuberosus (PT) were collected in the farm from the Federal University of Amazonas. The roots were cleaned and washed with distillated water to remove physical dirt. The washed roots were stored under refrigeration temperature until use. All reagents used were analytical grade.

\subsection{Starch extraction}

The starches from Xanthosoma sagittifolium and Pachyrhizus tuberosus, named as XAS and PTS, respectively, were extracted using methodology adapted from (Ascheri et al., 2014). Successive washes followed by decantation and filtration with a polyester mesh $(40 \mathrm{~cm} \mathrm{x} 40 \mathrm{~cm})$ at room temperature were realized until the samples were visually appearing a starch. Subsequently, it was air dried (Solab, model SL-100, SP, Brazil) at $50^{\circ} \mathrm{C}$ for $12 \mathrm{~h}$ and passed through a $48 \mathrm{Mesh}$ sieve to homogenize the samples.

\subsection{Proximate composition analysis of raw material}

The proximate composition of XA and PT samples was determined following the methods of Association of Official Analytical Chemists (2006). Moisture (method 934.06), crude protein (method 990.03), crude fiber (Method 978.10), total fat (method 983.23) and ash contents (method 942.05). The carbohydrate content was estimated by difference. Analysis were conducted in triplicate.

\subsection{Microstructure and morphology observations}

In order to investigate the presence of calcium oxalate raphides in XA and PT rhizomes an optical microscope Primo Star (Carl Zeiss, Jena, Germany) was used. Cross and longitudinal sections in the direction of the roots were made freehand with stainless steel blades. The anatomical investigation was performed with XA and PT fresh rhizomes. Thin sections were gently placed on glass slides with a drop of distilled water and glass covered for observation. The external morphology, shape and distribution of XAS and PTS granules were observed by scanning electron microscopy (SEM). XAS and PTS powder were sprinkled onto double-sided adhesive tape, attached to circular specimen stubs, coated with silver under $6 \times 10^{-1} \mathrm{mbar}$ ultrapure argon vacuum from Baltec (SCD 005 Sputter Coater, Balzers, Liechtenstein) for 150s, examined at $5 \mathrm{kV}$ and photographed (TM3030 Plus, Hitachi, Tokyo, Japan).

\subsection{Thermal processing and drying conditions}

The tuber samples were peeled off and manual sliced into approximately $2 \mathrm{~cm} \times 2 \mathrm{~cm}$ thickness using a stainless-steel knife. The XA and PT samples were separated in two groups, uncooked and cooked. The samples were cooked in boiling water for $40 \mathrm{~min}$ (time previously tested as sufficient to obtain soft roots for consumption). Uncooked and cooked slices samples were air-dried at $105^{\circ} \mathrm{C}$ until constant weight. Dried samples were separated, milled in domestic blender and passed through a $0.5 \mathrm{~mm}$ sieve. The milled samples were stored in air-tight containers prior to the determination of their anti-nutrient compositions.

\subsection{Anti-nutrients contents before and after thermal processing}

Anti-nutrients were determined for the uncooked and cooked samples, with methodology from Kumar et al. (2017) and expressed as calcium oxalate content. The calcium oxalate content was investigated by titration a previously acidified aliquot of the samples with $3 \mathrm{~N} \mathrm{H}_{2} \mathrm{SO}_{4}$ against $0.1 \mathrm{~N} \mathrm{KMnO}_{4}$ solutions under $90{ }^{\circ} \mathrm{C}$, until a pink color persisted. The procedure was repeated in triplicate.

\subsection{Functional properties of the starches}

Water-binding capacity, $\mathrm{pH}$ and gel clarity

WBC of XAS and PTS was gravimetrically measured according to methodology from Jiang et al. (2012). The WBC was calculated with the following Equation 1:

$W B C=\left(\frac{W_{1}-W_{0}}{W_{0}}\right) \times 100$

where $W_{0}$ is the initial weight of the dried starch samples, and $W_{1}$ is the weight of swollen starch samples. The $\mathrm{pH}$ of $1 \%$ starch/distilled water suspensions was measured using a digital $\mathrm{pH}$ meter. Gel clarity was expressed as light transmittance percentage (T\%) and measured in triplicate at $650 \mathrm{~nm}$ with a Cary 100 spectrophotometer (Agilent Technologies Inc., Santa Clara, CA, USA) according to Craig et al. (1989).

\section{Crystallinity degree}

The crystallinity degree (CrD) of XAS and PTS was analyzed with an X-Ray diffractometer (Ultima IV, Rigaku Corporation, Tokyo, Japan) in the angular region $2^{\circ}$ to $50^{\circ}(2 \theta)$ at $0.05^{\circ}$ per second $(2 \theta)$ in continuous scanning mode with $\mathrm{CuKa}$ radiation generated at $40 \mathrm{kV}$ and $20 \mathrm{~mA}$. CrD of samples was calculated as described by Bendaoud et al. (2017).

\section{Fourier transform infrared spectroscopy}

Infrared spectroscopy (FTIR) was used to evaluate the molecular structure of XAS and PTS. A Frontier FTIR/FIR spectrophotometer (model 98737, Perkin Elmer Spectrum, CT, USA) equipped with a Universal Attenuated Total Reflectance (ATR) cell device was used and the analysis were carried out from $4000-400 \mathrm{~cm}^{-1}$ wavenumbers. All spectra were registered with a $4 \mathrm{~cm}^{-1}$ resolution in transmission mode by averaging 60 scans and samples were analyzed as potassium bromide $(\mathrm{KBr})$ disks. 


\section{Thermal degradation}

Thermogravimetric (TG) and differential thermal analyses (DTA) were used to investigate the thermal degradation behavior of the XAS and PTS. The analyses were carried out under nitrogen atmosphere on TGA Q-500 equipment (TA Instruments, New Castle, USA). The samples $(10 \mathrm{mg}$ ) were heated from $25^{\circ} \mathrm{C}$ to $700{ }^{\circ} \mathrm{C}$ at a $10^{\circ} \mathrm{C} / \mathrm{min}$.

\subsection{Statistical analysis}

Experimental data was submitted to variance analysis (ANOVA) and significant differences between means were established at $\mathrm{p} \leq 0.05$. Tukey's test was applied.

\section{Results and discussion}

\subsection{Proximate composition analysis of raw material}

Information about the nutritional composition of unusual tuberous roots, such as XA and PT, is important because of the common use of this food for the local communities in South America. The results of proximate composition from XA and $\mathrm{PT}$ are listed in Table 1. In general, XA and PT presented high moisture content, 77 and $89 \mathrm{~g} / 100 \mathrm{~g}$ of fresh sample, respectively. A similar value, $77 \mathrm{~g} / 100 \mathrm{~g}$, of moisture were found in sweet potato (Uchechukwu-Agua et al., 2015). The major nutrient found in XA and PT was carbohydrates. Those were lower than the values (18-37 g/100g) determined for red-flesh X. sagittifolium (Sefa-Dedeh \& Agyir-Sackey, 2004). The chemical composition of the studied tubers shown low contents of fats, crude fibers and ashes. The crude protein composition was significantly higher in XA than PT. The crude protein in PT was inferior to values (4.3-7.4\%) quantified in other works with different phenotypes of $P$. tuberosus (Ascheri et al., 2014). The flour from X. robustum presented $6.8 \%$ of crude protein (Londoño-Restrepo et al., 2014). The major variety on the nutritional composition of these tubers are related to the differences between species, phenotypes and environmental growth conditions.

\subsection{Microstructure and morphology observations}

The light microscopic observations were used to visualize the presence of calcium oxalate raphides in sections of XA and PT fresh rhizomes. It was observed in XA and PT fresh rhizome sections, the presence of raphides aggregates with spherical shape, which is related to calcium oxalate as shown in Figure 1.

Table 1. Proximate composition of two Amazonian tubers.

\begin{tabular}{lcc}
\hline \multicolumn{1}{c}{$\begin{array}{c}\text { Composition } \\
(\mathrm{g} / 100 \mathrm{~g})^{*}\end{array}$} & $\begin{array}{c}\text { Xanthosoma } \\
\text { sagittifolium }\end{array}$ & $\begin{array}{c}\text { Pachyrhizus } \\
\text { tuberosus }\end{array}$ \\
\hline Moisture & $77.1 \pm 2.82^{\mathrm{a}}$ & $89.0 \pm 3.7^{\mathrm{b}}$ \\
Ashes & $1.1 \pm 0.09^{\mathrm{a}}$ & $0.6 \pm 0.43^{\mathrm{a}}$ \\
Crude proteins & $4.4 \pm 0.42^{\mathrm{a}}$ & $1.1 \pm 0.23^{\mathrm{b}}$ \\
Total fats & $0.2 \pm 0.06^{\mathrm{a}}$ & $0.1 \pm 0.03^{\mathrm{a}}$ \\
Crude fibers & $0.7 \pm 0.07^{\mathrm{a}}$ & $1.20 \pm 0.08^{\mathrm{b}}$ \\
Carbohydrates & $16.6 \pm 3.48^{\mathrm{a}}$ & $8.03 \pm 4.30^{\mathrm{a}}$ \\
\hline
\end{tabular}

Data presented as mean \pm standard deviation $(n=3)$; ${ }^{\star}$ Dry basis (except moisture content); Lowercase letters ${ }^{\mathrm{a}, \mathrm{b}}$ overwritten in the same line shows significant difference $(\mathrm{p}<0.05)$ by Tukey's test.
The shape (needles, spherical aggregates, crystal sand, styloid, and prisms) or tissue locations of calcium oxalate crystals are related to growth conditions of each species (Ilarslan et al., 1997).

The morphology and distribution of XAS and PTS starch granules were observed by scanning electronic microscopy and are shown in Figure 2. The starch granules presented ovoid and circular shapes. The starch granules of both species shown dimensions varying from $3.6 \mu \mathrm{m}$ to $14 \mu \mathrm{m}$ and their surfaces are smooth. It was noted that the starch granules formed a Lego-like macro particles (Londoño-Restrepo et al., 2018), which exhibit irregular and dense shapes. Similar shapes and sizes were observed in Dioscorea opposita tuber starch (Chen et al., 2017a). The starch form $X$. robustum presented a circular shape and size between 8 and $35 \mu \mathrm{m}$ (Londoño-Restrepo et al., 2014).

\subsection{Anti-nutrients contents before and after thermal processing}

The calcium oxalate content as an anti-nutrient in $\mathrm{XA}$ and PT were determined before and after thermal treatment. The results are listed in Table 2 . The cooking effect promoted a relevant reduction of more than $85 \%$ in oxalate content for both tubers $(\mathrm{p}<0.05)$. The uncooked XA and PT presented high content of calcium oxalate, when compared to the values determined for the cooked tubers. The cooking effect in the reduction of calcium oxalate content is in accordance to the records in the literature for boiled vegetables (Akpan \& Umoh, 2004; Savage et al., 2000). Studies with two species of $X$. sagittifolium reported an oxalate content in fresh samples ranging from 254 to $460 \mu \mathrm{g} / 100 \mathrm{~g}$ and a significant reduction
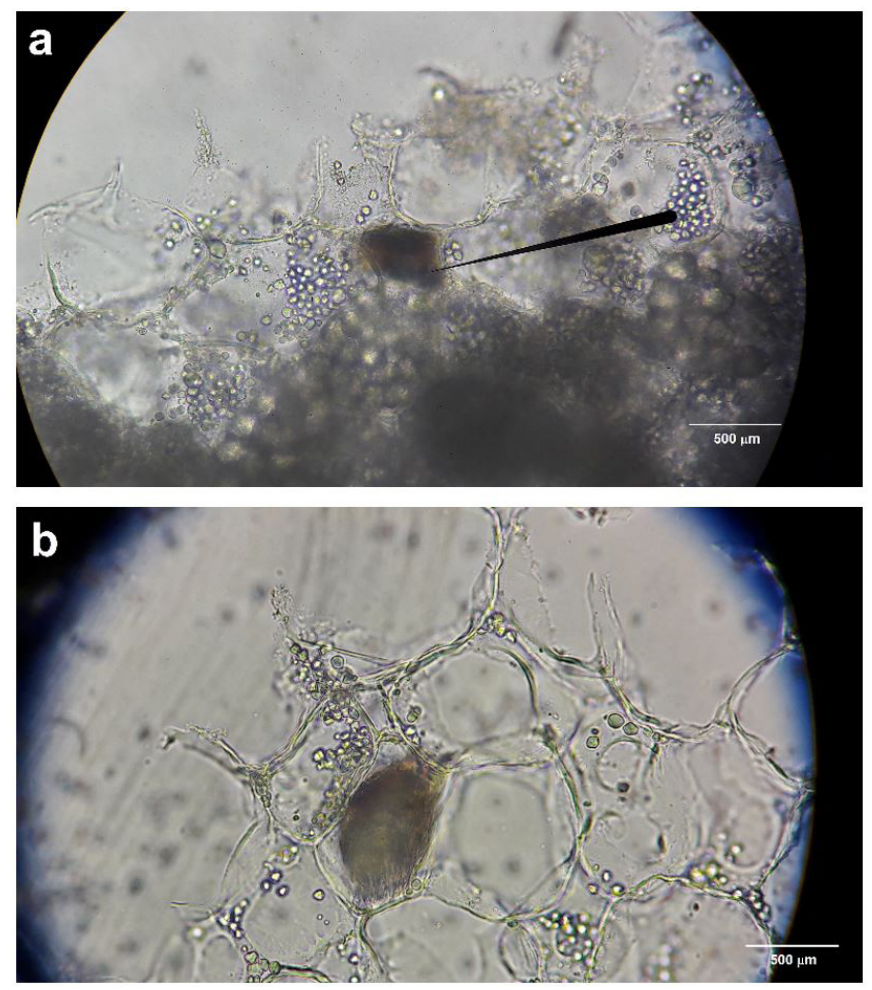

Figure 1. Calcium oxalate raphides in (a) Xanthosoma sagittifolium and (b) Pachyrhizus tuberosus fresh sections roots observed within a 40x magnification. 

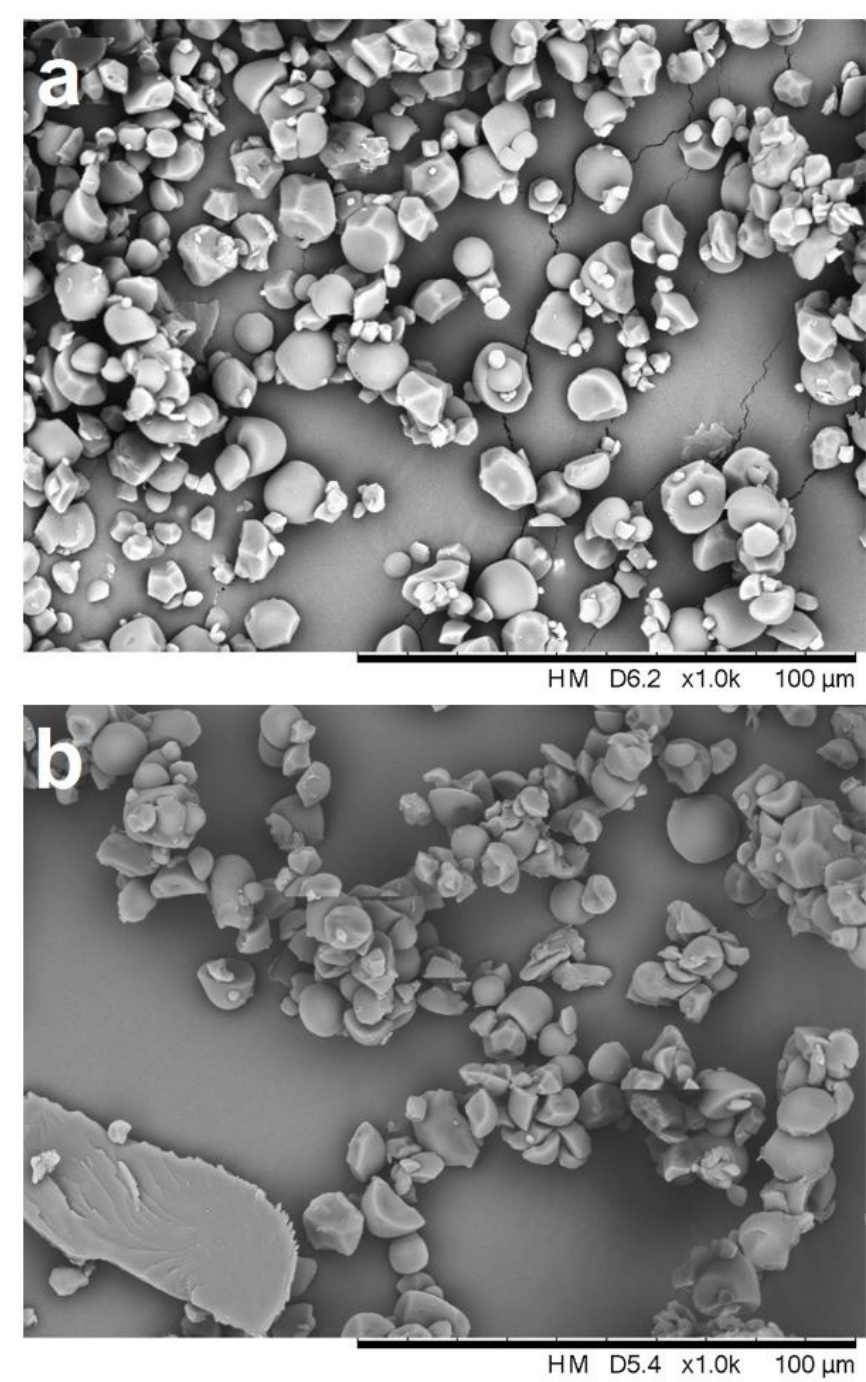

Figure 2. SEM observations of (a) Xanthosoma sagittifolium and (b) Pachyrhizus tuberosus starches microstructure within a $1000 \mathrm{x}$ magnification.

of $50 \%$ in this substance by drying it in double roller drum dryer (Sefa-Dedeh \& Agyir-Sackey, 2004). The reduction of more than $70 \%$ of oxalate content in flours prepared with pre-cooked slices from Colocasia esculenta in lemon solution was also reported by Kumar et al. (2017). For these authors, the oxalates are related to acridity in Colocasia tubers and may interfere with bioavailability of other nutrients. Hence, the reduction of calcium oxalate content determined in the present work is an important contribution to Amazonian and vegan diets, which have a high consumption of vegetables.

\subsection{Functional properties of the starches}

\section{Water-binding capacity, $\mathrm{pH}$ and gel clarity}

The functional properties of the isolated starches from $X$. sagittifolium and $P$. tuberosus were evaluated according to its water-binding capacity, $\mathrm{pH}$ and gel clarity. The capacity and intensity of water absorption within the starch granules are described as water-binding capacity (WBC) (Deepika et al., 2017).
Table 2. Calcium oxalate content $(\mathrm{mg} / 100 \mathrm{~g})$ in edible tubers.

\begin{tabular}{lcc}
\hline \multicolumn{1}{c}{ Sample } & Uncooked & Cooked \\
\hline Xanthosoma sagittifolium & $699.27 \pm 0.1^{\mathrm{a}, \mathrm{A}}$ & $78.51 \pm 1.9^{\mathrm{b}, \mathrm{A}}$ \\
Pachyrhizus tuberosus & $499.67 \pm 0.1^{\mathrm{a}, \mathrm{B}}$ & $60.66 \pm 0.9^{\mathrm{b}, \mathrm{B}}$ \\
\hline
\end{tabular}

Results are expressed as mean \pm standard deviation $(n=3)$. Lowercase letters a,b overwritten in the same line shows significant difference $(\mathrm{p}<0.05)$ by T-test. Uppercase letters ${ }^{A, B}$ overwritten in the same column shows significant difference $(\mathrm{p}<0.05)$ by Tukey's test.

WBC is associated to the formation of hydrogen and covalent bonds between water and the polysaccharides chains in starch (Jiang et al., 2012). PTS presented a higher WBC then XAS. The results of WBC were $192 \pm 17 \mathrm{~g} / 100 \mathrm{~g}$ and $292 \pm 18 \mathrm{~g} / 100 \mathrm{~g}$ for XAS and PTS, respectively. Similar values (188 - $257 \mathrm{~g} / 100 \mathrm{~g})$ of WBC in Dioscorea opposita starch treated with different heat temperatures were reported to influence the gelatinization degree (Chen et al., 2017a). Low values of WBC were attributed to the V-type of the crystallinity pattern in starch from Dioscorea alata L. due to compact granules structure (Mao et al., 2018). The $\mathrm{pH}$ of a $1 \%$ aqueous suspension (w/v) of XAS and PTS were $4.82 \pm 0.03$ and $3.84 \pm 0.01$, respectively. Starch gels clarity is a significant quality for foods because of the influence on its viscosity and appearance (Craig et al., 1989). The isolated starch XAS presented lower gel clarity of $28.5 \pm 0.3 \%$ then the value, $40.8 \pm 0.6 \%$, from PTS. A lower percentage of transmittance is related to opaquer gels (Craig et al., 1989). Gelling is related to granule properties, such as amylose content, $\mathrm{pH}$, granules morphology, WBC and its internal arrangement (Deepika et al., 2013). Paste clarity in normal starches varied from $10 \%$ (rice) to $88 \%$ (potato), and starch from roots like cassava is around 50\% (Sánchez et al., 2010). Gels from cereals exhibit lower clarity than those from roots and tubers (Sánchez et al., 2010).

\section{Crystallinity degree}

The starches, XAS and PTS, were analyzed by X-ray diffractometry (XRD) to investigate their type of structural arrangement. X-ray diffraction can reveal the structure order and double helices arrangement, thus reflecting the three-dimensional crystallinity of starch samples (Hornung et al., 2017). The crystalline peaks were analyzed in the interval from $2^{\circ}$ to $50^{\circ}(2 \theta)$ and the crystallinity degree was calculated as the ratio of the crystalline diffraction area to the total diffraction area (Huang et al., 2016). The XRD patterns of XAS and PTS, in Figure 3, show that the starches presented reflections intensities at $15^{\circ}, 17^{\circ}, 18^{\circ}, 20^{\circ}$ and $23^{\circ}$ at $2 \theta$ angles, which is typical in an A-type starch structure (Lawal et al., 2008; Zhu, 2016). This result is in accordance with the XRD patterns found in Dioscorea opposita flours and in Xanthosoma sagittifolium native starches (Chen et al. 2017b; Perez-Rea et al., 2013). Crystal type of starch granules possess a closest relation to the amylopectin chains length, in which A, B and C-type crystallinity are linked to short, long and medium chain lengths (Cheetham \& Tao, 1998). Relative crystallinities of rice starches were inversely associated to the content of apparent amylose (Chung et al. 2011). Other authors reported an amylose content in Pachyrhizus ahipa and P. erosus ranging from 11 to $23 \%$ (Forsyth et al., 2002). The CrD of XAS was, near to $16.6 \%$, a higher value than PTS, around $10.0 \%$. These 
results are lower than the values, $45 \%$, found in native starches from Xanthosoma sagittifolium and 34.3\% from Pachyrhizus erosus (Gunaratne \& Hoover, 2002; Stevenson et al., 2007).

\section{Fourier transform infrared spectroscopy}

The infrared spectrometry (FTIR) is an important tool that supply information about chemical groups and their vibrational state associated to changes in the chemical composition of raw materials (García-Salcedo et al., 2018). The FTIR spectra are shown in Figure 4. The regions near 3307 and $3308 \mathrm{~cm}^{-1}$ are assigned to $-\mathrm{OH}$ stretching (Londoño-Restrepo et al., 2018). The bands between $2980-2860 \mathrm{~cm}^{-1}$ are related to vibrational stretch of C-H (Londoño-Restrepo et al., 2018). Bands around $1650 \mathrm{~cm}^{-1}$ are associated to stretching vibration of $\mathrm{C}=\mathrm{O}$ (amide I) and representing water molecules in the starch amorphous region (Dankar et al., 2018; Kizil et al., 2002; Olsson \& Salmén, 2004). The band near $1420 \mathrm{~cm}^{-1}$ is associated to $-\mathrm{CH}_{2}$ bending and -COO stretch (Cael et al., 1975; Dankar et al., 2018). Vibrations of glucosidic bond $(\mathrm{C}-\mathrm{O}-\mathrm{C})$ are attributed to the band at $1160 \mathrm{~cm}^{-1}$ (Olsson \& Salmén, 2004.). Higher intensity bands located at $\sim 1120 \mathrm{~cm}^{-1}$ are associated to $\mathrm{C}-\mathrm{O}$ and $\mathrm{C}-\mathrm{C}$ stretching vibrations of polysaccharide molecules and have been

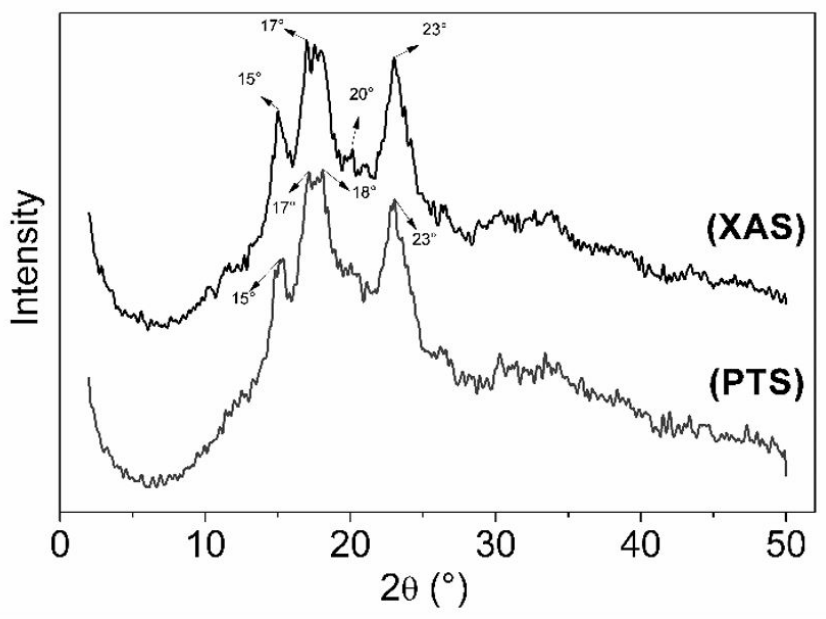

Figure 3. XRD patterns of XAS (black line) and PTS (gray line).

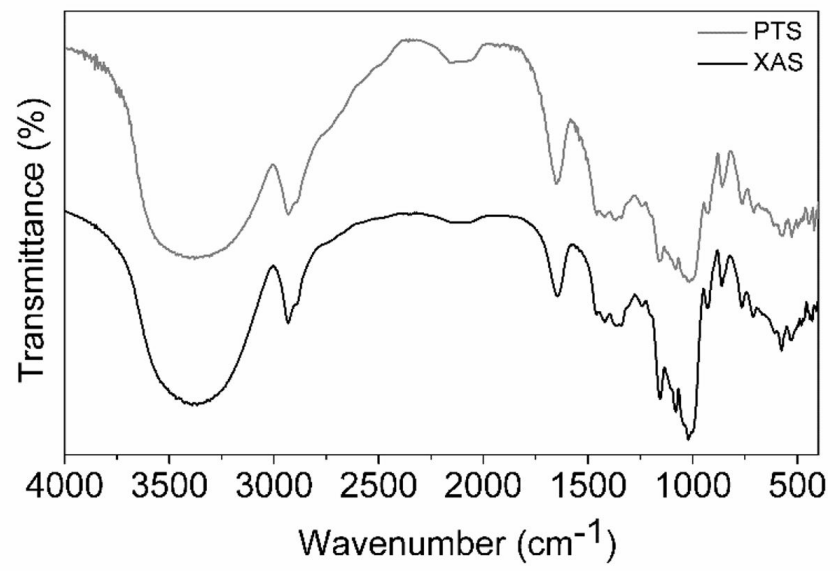

Figure 4. FTIR spectra of XAS (black line) and PTS (gray line). link to the degree of the hydration of the sample (Cael et al., 1975; Contreras-Jiménez et al., 2019).

\section{Thermal degradation}

Figure 5 shows the thermogravimetric (TGA) and differential analyses (DTA) of the decomposition behavior of XAS and PTS. Both samples were heated from $25^{\circ} \mathrm{C}$ to $700^{\circ} \mathrm{C}$ and their thermal decomposition process was analyzed through the weight loss (\%) and rate of weight loss $\left(\% /{ }^{\circ} \mathrm{C}\right)$. As observed in Figure $5 \mathrm{a}$, the first mass loss on XAS, $\sim 11 \%$, can be related to moisture content on starch and occurs until $\sim 150^{\circ} \mathrm{C}$. The initial degradation temperature $\left(\mathrm{T}_{\text {onset }}\right)$ takes place at $\sim 293^{\circ} \mathrm{C}$ and the peak temperature at $\sim 310^{\circ} \mathrm{C}$. This second stage of mass loss is associated to main decomposition of the macromolecules on starch. Total mass loss detected at $700^{\circ} \mathrm{C}$ was of $88.1 \%$, remaining inorganic ashes after the organic matter carbonization. Similar degradation behavior was described in X. robustum starch (Londoño-Restrepo et al., 2014). Figure 5b shows the thermal degradation behavior of PTS. It also noted an initial mass loss, closely to $10 \%$ of weight, which occurs until $150{ }^{\circ} \mathrm{C}$ and can be correlated to moisture content. $\mathrm{T}_{\text {onset }}$ and peak temperature of PTS occurred at $\sim 291{ }^{\circ} \mathrm{C}$ and $309^{\circ} \mathrm{C}$, respectively. Total mass loss was of almost $90 \%$ at $700{ }^{\circ} \mathrm{C}$. Initial thermal degradation at $220^{\circ} \mathrm{C}$ for anhydrous potato starch is describe in the literature (Monnier et al., 2017).
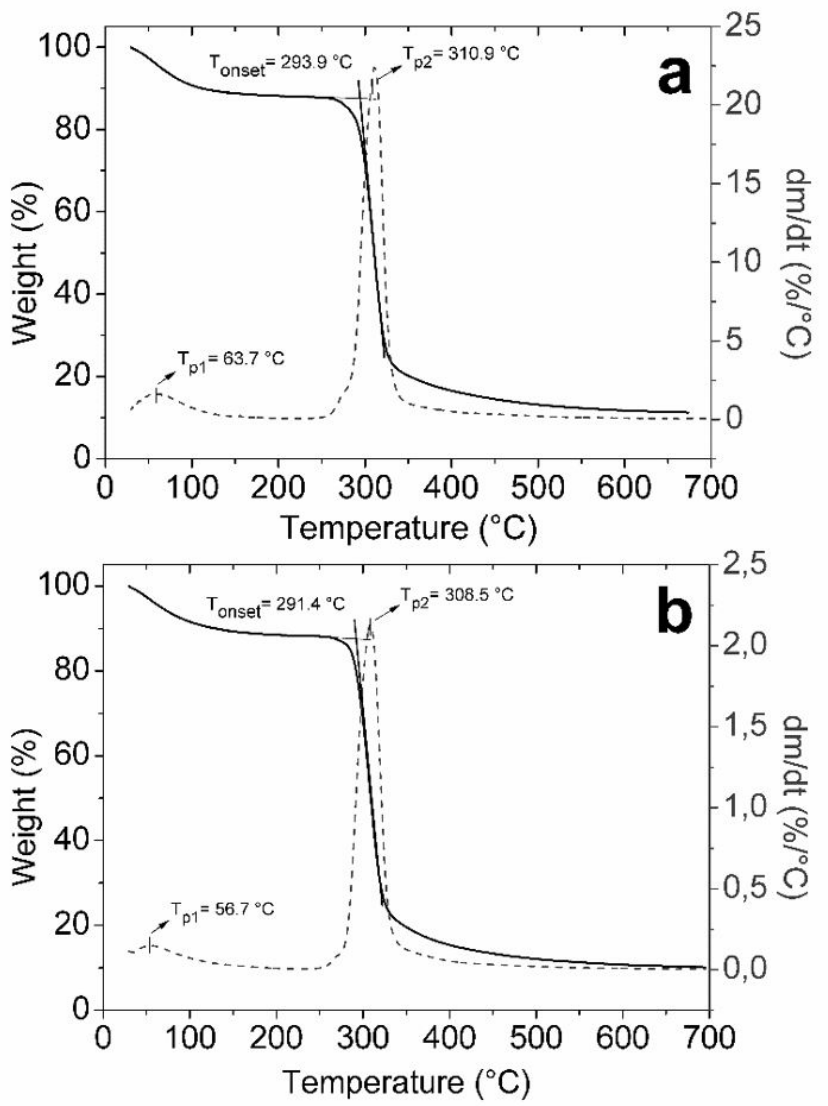

Figure 5. TGA (black line) and DTA (gray dash line) curves of XAS (a) and PTS (b). 


\section{Conclusions}

The two species of wild tubers studied in this work presented a good physico-chemical composition based on their major amount of carbohydrates, low fats content and relevant amount of crude protein. These tubers were cooked into boiling water to verify the reduction of calcium oxalate content after the application of the thermal processing. A significant reduction of more than $85 \%$ in calcium oxalate content was found for both species after cooking. The functional properties and physico-chemical characteristics of starches from these species were also investigated. The isolated starches presented lower gel clarity and a slightly high water-binding capacity, which may be related to the internal arrangement and morphology of the starch granules. A-type starch structure was found in the isolated starches from Xanthosoma sagittifolium and Pachyrhizus tuberosus. XAS and PTS starches presented low values of crystallinity degree, which may be an indication of higher amounts of amylose in it. High intensity bands related to vibrations of glucosidic bonds and others functional groups of polysaccharides were observed by infrared spectrum in XAS and PTS. The thermal behavior analysis of the starches reveled initial degradation temperatures ranging around $\sim 290^{\circ} \mathrm{C}$ and peak temperatures close to $\sim 310^{\circ} \mathrm{C}$. Thermal performance of starches generally occurs in similar way due to the degradation of macromolecules in this temperature range. Thus, Xanthosoma sagittifolium and Pachyrhizus tuberosus tubers presented good characteristics to be consumed as a cooked vegetable or as a potential ingredient in food products based on the properties of their starches. Furthermore, the identification of such important properties of these traditional foods of Amazonian communities contributes to increase the concern about conservation of indigenous knowledge and the rain-forest protection.

\section{Acknowledgements}

The authors are grateful to Eloisa Mano Macromolecules Institute (IMA) of Rio de Janeiro Federal University (UFRJ) for providing access to tools and facilities.

\section{References}

Akpan, E. J., \& Umoh, I. B. (2004). Effect of heat and tetracycline treatments on the food quality and acridity factors in cocoyam [Xanthosoma sagittifolium (L) Schott]. Pakistan Journal of Nutrition, 3(4), 240-243. http://dx.doi.org/10.3923/pjn.2004.240.243.

Ascheri, J. L. R., Zamudio, L. H. B., Carvalho, C. W. P., Arevalo, A. M., \& Fontoura, L. M. (2014). Extraction and characterization of starch fractions of five phenotypes Pachyrhizus tuberosus (Lam.) Spreng. Food and Nutrition Sciences, 5(19), 1875-1885. http://dx.doi. org/10.4236/fns.2014.519200.

Association of Official Analytical Chemists - AOAC. (2006). Official methods of analysis of the AOAC (18th ed.). Washington: AOAC.

Bendaoud, A., Kehrbusch, R., Baranov, A., Duchemin, B., Maigret, J. E., Falourd, X., Staiger, M. P., Cathala, B., Lourdin, D., \& Leroy, E. (2017). Nanostructured cellulose-xyloglucan blends via ionic liquid/ water processing. Carbohydrate Polymers, 168, 163-172. http://dx.doi. org/10.1016/j.carbpol.2017.03.080. PMid:28457437.

Boakye, A. A., Wireko-Manu, F. D., Oduro, I., Ellis, W. O., Gudjónsdóttir, M., \& Chronakis, I. S. (2018). Utilizing Cocoyam (Xanthosoma sagittifolium) for food and nutrition security: a review. Food Science \& Nutrition, 6(4), 703-713. http://dx.doi.org/10.1002/fsn3.602. PMid:29983932.

Cael, J. J., Koenig, J. L., \& Blackwell, J. (1975). Infrared and Raman spectroscopy of carbohydrates. Part VI: normal coordinate analysis of V-amylose. Biopolymers, 14(9), 1885-1903. http://dx.doi.org/10.1002/ bip.1975.360140909.

Cheetham, N. W. H., \& Tao, L. (1998). Variation in crystalline type with amylose content in maize starch granules: An X-ray powder diffraction study. Carbohydrate Polymers, 36(4), 277-284. http:// dx.doi.org/10.1016/S0144-8617(98)00007-1.

Chen, X., Li, X., Mao, X., Huang, H., Wang, T., Qu, Z., Miao, J., \& Gao, W. (2017a). Effects of drying processes on starch-related physicochemical properties, bioactive components and antioxidant properties of yam flours. Food Chemistry, 224, 224-232. http://dx.doi.org/10.1016/j. foodchem.2016.12.028. PMid:28159260.

Chen, X., Lu, J., Li, X., Wang, Y., Miao, J., Mao, X., Zhao, C., \& Gao, W. (2017b). Effect of blanching and drying temperatures on starch-related physicochemical properties, bioactive components and antioxidant activities of yam flours. Lebensmittel-Wissenschaft + Technologie, 82, 303-310. http://dx.doi.org/10.1016/j.lwt.2017.04.058.

Chung, H.-J., Liu, Q., Lee, L., \& Wei, D. (2011). Relationship between the structure, physicochemical properties and in vitro digestibility of rice starches with different amylose contents. Food Hydrocolloids, 25(5), 968-975. http://dx.doi.org/10.1016/j.foodhyd.2010.09.011.

Contreras-Jiménez, B., Vázquez-Contreras, G., de los Ángeles CornejoVillegas, M., del Real-López, A., \& Rodríguez-García, M. E. (2019). Structural, morphological, chemical, vibrational, pasting, rheological, and thermal characterization of isolated jicama (Pachyrhizus spp.) starch and jicama starch added with $\mathrm{Ca}(\mathrm{OH})_{2}$. Food Chemistry, 283, 83-91. http://dx.doi.org/10.1016/j.foodchem.2019.01.013. PMid:30722929.

Craig, S. A. S., Maningat, C. C., Seib, P. A., \& Hoseney, R. C. (1989). Starch paste clarity. Cereal Chemistry, 66, 173-182.

Dankar, I., Haddarah, A., Omar, F. E. L., Pujolà, M., \& Sepulcre, F. (2018). Characterization of food additive-potato starch complexes by FTIR and X-ray diffraction. Food Chemistry, 260, 7-12. http:// dx.doi.org/10.1016/j.foodchem.2018.03.138. PMid:29699684.

Deepika, V., Anima, P., Hermenean, A., Yáñez-Gascón, M. J., PérezSánchez, H., \& Kumar, K. J. (2017). Effect of dry heating and ionic gum on the physicochemical and release properties of starch from Dioscorea. International Journal of Biological Macromolecules, 95, 557-563. http://dx.doi.org/10.1016/j.ijbiomac.2016.11.064. PMid:27871789.

Deepika, V., Kumar, K. J., \& Anima, P. (2013). Isolation and physicochemical characterization of sustained releasing starches from Dioscorea of Jharkhand. International Journal of Biological Macromolecules, 55, 193-200. http://dx.doi.org/10.1016/j.ijbiomac.2012.11.027. PMid:23201777.

Díaz, A., Dini, C., Viña, S. Z., \& García, M. A. (2016). Starch extraction process coupled to protein recovery from leguminous tuberous roots (Pachyrhizus ahipa). Carbohydrate Polymers, 152, 231-240. http://dx.doi.org/10.1016/j.carbpol.2016.07.004. PMid:27516269.

Falade, K. O., \& Okafor, C. A. (2013). Physicochemical properties of five cocoyam (Colocasia esculenta and Xanthosoma sagittifolium) starches. Food Hydrocolloids, 30(1), 173-181. http://dx.doi.org/10.1016/j. foodhyd.2012.05.006.

Forsyth, J. L., Ring, S. G., Noel, T. R., Parker, R., Cairns, P., Findlay, K., \& Shewry, P. R. (2002). Characterization of starch from tubers of yam bean (Pachyrhizus ahipa). Journal of Agricultural and Food 
Chemistry, 50(2), 361-367. http://dx.doi.org/10.1021/jf0108922. PMid:11782208.

García-Salcedo, Á. J., Torres-Vargas, O. L., del Real, A., ContrerasJiménez, B., \& Rodriguez-Garcia, M. E. (2018). Pasting, viscoelastic, and physicochemical properties of chia (Salvia hispanica L.) flour and mucilage. Food Structure, 16, 59-66. http://dx.doi.org/10.1016/j. foostr.2018.03.004.

Graf, B. L., Zhang, L., Corradini, M. G., Kuhn, P., Newman, S. S., Salbaum, J. M., \& Raskin, I. (2018). Physicochemical differences between malanga (Xanthosoma sagittifolium) and potato (Solanum tuberosum) tubers are associated with differential effects on the gut microbiome. Journal of Functional Foods, 45, 268-276. http://dx.doi. org/10.1016/j.jff.2018.04.032. PMid:30416540.

Gunaratne, A., \& Hoover, R. (2002). Effect of heat-moisture treatment on the structure and physicochemical properties of tuber and root starches. Carbohydrate Polymers, 49(4), 425-437. http://dx.doi. org/10.1016/S0144-8617(01)00354-X.

Hornung, P. S., Ávila, S., Lazzarotto, M., Silveira Lazzarotto, S. R., Andrade de Siqueira, G. L., Schnitzler, E., \& Ribani, R. H. (2017). Enhancement of the functional properties of Dioscoreaceas native starches: mixture as a green modification process. Thermochimica Acta, 649, 31-40. http://dx.doi.org/10.1016/j.tca.2017.01.006.

Huang, H., Jiang, Q., Chen, Y., Li, X., Mao, X., Chen, X., Huang, L., \& Gao, W. (2016). Preparation, physico-chemical characterization and biological activities of two modified starches from yam (Dioscorea Opposita Thunb.). Food Hydrocolloids, 55, 244-253. http://dx.doi. org/10.1016/j.foodhyd.2015.11.016.

Ilarslan, H., Palmer, R. G., Imsande, J., \& Horner, H. T. (1997). Quantitative determination of calcium oxalate and oxalate in developing seeds of soybean (Leguminosae). American Journal of Botany, 84(8), 1042-1046. http://dx.doi.org/10.2307/2446147. PMid:21708659.

Jayakody, L., Hoover, R., Liu, Q., \& Donner, E. (2007). Studies on tuber starches. II. Molecular structure, composition and physicochemical properties of yam (Dioscorea sp.) starches grown in Sri Lanka. Carbohydrate Polymers, 69(1), 148-163. http://dx.doi.org/10.1016/j. carbpol.2006.09.024.

Jiang, Q., Gao, W., Li, X., Xia, Y., Wang, H., Wu, S., Huang, L., Liu, C., \& Xiao, P. (2012). Characterizations of starches isolated from five different Dioscorea L. species. Food Hydrocolloids, 29(1), 35-41. http://dx.doi.org/10.1016/j.foodhyd.2012.01.011.

Kizil, R., Irudayaraj, J., \& Seetharaman, K. (2002). Characterization of irradiated starches by using FT-Raman and FTIR spectroscopy. Journal of Agricultural and Food Chemistry, 50(14), 3912-3918. http://dx.doi.org/10.1021/jf011652p. PMid:12083858.

Kumar, V., Sharma, H. K., \& Singh, K. (2017). Effect of precooking on drying kinetics of taro (Colocasia esculenta) slices and quality of its flours. Food Bioscience, 20, 178-186. http://dx.doi.org/10.1016/j. fbio.2017.10.003.

Lawal, O. S., Lechner, M. D., \& Kulicke, W. M. (2008). Single and multistep carboxymethylation of water yam (Dioscorea alata) starch: Synthesis and characterization. International Journal of Biological Macromolecules, 42(5), 429-435. http://dx.doi.org/10.1016/j. ijbiomac.2008.02.006. PMid:18394696.

Londoño-Restrepo, S. M., Rincón-Londoño, N., Contreras-Padilla, M., Acosta-Osorio, A. A., Bello-Pérez, L. A., Lucas-Aguirre, J. C., Quintero, V. D., Pineda-Gómez, P., del Real-López, A., \& Rodríguez-García, M. E. (2014). Physicochemical, morphological, and rheological characterization of Xanthosoma robustum Lego-like starch. International Journal of Biological Macromolecules, 65, 222-228. http://dx.doi.org/10.1016/j.ijbiomac.2014.01.035. PMid:24463263.
Londoño-Restrepo, S. M., Rincón-Londoño, N., Contreras-Padilla, M., Millan-Malo, B. M., \& Rodriguez-Garcia, M. E. (2018). Morphological, structural, thermal, compositional, vibrational, and pasting characterization of white, yellow, and purple Arracacha Lego-like starches and flours (Arracacia xanthorrhiza). International Journal of Biological Macromolecules, 113, 1188-1197. http://dx.doi. org/10.1016/j.ijbiomac.2018.03.021. PMid:29522823.

Mao, X., Lu, J., Huang, H., Gao, X., Zheng, H., Chen, Y., Li, X., \& Gao, W. (2018). Four types of winged yam (Dioscorea alata L.) resistant starches and their effects on ethanol-induced gastric injury in vivo. Food Hydrocolloids, 85, 21-29. http://dx.doi.org/10.1016/j. foodhyd.2018.06.036.

Monnier, X., Maigret, J. E., Lourdin, D., \& Saiter, A. (2017). Glass transition of anhydrous starch by fast scanning calorimetry. Carbohydrate Polymers, 173, 77-83. http://dx.doi.org/10.1016/j. carbpol.2017.05.042. PMid:28732921.

Odeku, O. A. (2013). Potentials of tropical starches as pharmaceutical excipients: a review. Stärke, 65(1-2), 89-106. http://dx.doi.org/10.1002/ star.201200076.

Olsson, A. M., \& Salmén, L. (2004). The association of water to cellulose and hemicellulose in paper examined by FTIR spectroscopy. Carbohydrate Research, 339(4), 813-818. http://dx.doi.org/10.1016/j. carres.2004.01.005. PMid:14980824.

Otegbayo, B., Oguniyan, D., \& Akinwumi, O. (2014). Physicochemical and functional characterization of yam starch for potential industrial applications. Stärke, 66(3-4), 235-250. http://dx.doi.org/10.1002/ star.201300056.

Perez-Rea, D., Rojas, C., Carballo, S., Aguilar, W., Bergenståhl, B., \& Nilsson, L. (2013). Enzymatic hydrolysis of Canna indica, Manihot esculenta and Xanthosoma sagittifolium native starches below the gelatinization temperature. Stärke, 65(1-2), 151-161. http://dx.doi. org/10.1002/star.201200103.

Ramos-de-la-Peña, A. M., Renard, C. M. G. C., Wicker, L., \& ContrerasEsquivel, J. C. (2013). Advances and perspectives of Pachyrhizus spp. in food science and biotechnology. Trends in Food Science \& Technology, 29(1), 44-54. http://dx.doi.org/10.1016/j.tifs.2012.09.003.

Sánchez, T., Dufour, D., Moreno, I. X., \& Ceballos, H. (2010). Comparison of pasting and gel stabilities of waxy and normal starches from potato, maize, and rice with those of a novel waxy cassava starch under thermal, chemical, and mechanical stress. Journal of Agricultural and Food Chemistry, 58(8), 5093-5099. http://dx.doi.org/10.1021/ jf1001606. PMid:20356303.

Savage, G. P., Vanhanen, L., Mason, S. M., \& Ross, A. B. (2000). Effect of cooking on the soluble and insoluble oxalate content of some New Zealand foods. Journal of Food Composition and Analysis, 13(3), 201-206. http://dx.doi.org/10.1006/jfca.2000.0879.

Sefa-Dedeh, S., \& Agyir-Sackey, E. K. (2004). Chemical composition and the effect of processing on oxalate content of cocoyam Xanthosoma sagittifolium and Colocasia esculenta cormels. Food Chemistry, 85(4), 479-487. http://dx.doi.org/10.1016/S0308-8146(02)00244-3.

Stevenson, D. G., Jane, J., \& Inglett, G. E. (2007). Characterization of Jícama (Mexican potato) (Pachyrhizus erosus L. Urban) starch from taproots grown in USA and Mexico. Stärke, 59(3-4), 132-140. http:// dx.doi.org/10.1002/star.200600596.

Uchechukwu-Agua, A. D., Caleb, O. J., \& Opara, U. L. (2015). Postharvest handling and storage of fresh cassava root and products: a review. Food and Bioprocess Technology, 8(4), 729-748. http://dx.doi. org/10.1007/s11947-015-1478-z.

Zhu, F. (2016). Structure, properties, and applications of aroid starch. Food Hydrocolloids, 52, 378-392. http://dx.doi.org/10.1016/j. foodhyd.2015.06.023. 